\title{
Workers' safety in the construction industry in the southern West Bank of Palestine
}

\author{
M.I. Al-Sari" and I.A. Al-Khatib ${ }^{2}$
}

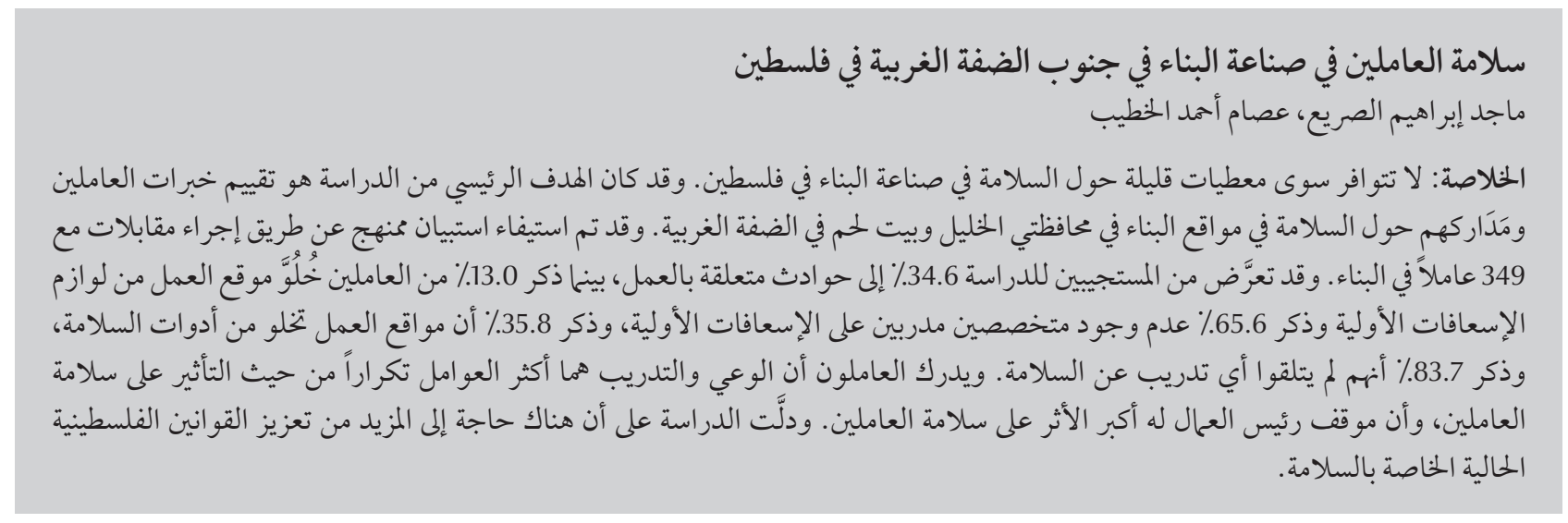

ABSTRACT There are few data about safety in the construction industry in Palestine. The main aim of the study was to assess worker's experiences and perceptions of safety at construction sites in Hebron and Bethlehem governorates of the West Bank. A structured questionnaire was completed through direct interviews with 349 construction workers. Of the respondents, 34.6\% had experienced work-related accidents, $13.0 \%$ and $65.6 \%$ indicated that their workplace did not have a first-aid kit or trained first-aid specialist respectively, $35.8 \%$ reported that their work sites did not have safety tools and $83.7 \%$ had not received safety training. Workers perceived that awareness and training were the most frequent factor affecting workers' safety, with the foreman position having the greatest impact on the workers' safety. Greater enforcement of the current Palestinian safety laws is needed.

\section{Sécurité des travailleurs dans l'industrie du bâtiment dans le sud de la Cisjordanie (Palestine)}

RÉSUMÉLesdonnéessurlasécuritédestravailleurssontraresdansl'industriedubâtimentenPalestine.Leprincipalobjectif de l'étude était d'évaluer l'expérience et la perception de la sécurité chez les travailleurs sur les sites de construction des gouvernorats d'Hébron et de Bethléem en Cisjordanie. Un questionnaire structuré a été rempli lors d'entretiens individuels avec 349 ouvriers du bâtiment. Au total, 34,6 \% d'entre eux avaient une expérience des accidents du travail ; $13,0 \%$ et 65,6\% respectivement ont indiqué que leur lieu de travail n'était pas équipé d'une trousse de premiers secours ou ne bénéficiait pas de la présence d'un secouriste qualifié ; 35,8 \% ont déclaré que leur lieu de travail ne disposait pas d'outils de sécurité et $83,7 \%$ n'avaient pas reçu de formation sur la sécurité. Les travailleurs considéraient que la sensibilisation et la formation étaient les facteurs influant le plus souvent sur leur sécurité, et que le rôle du contremaître était très important en la matière. Une application plus stricte des lois palestiniennes sur la sécurité est nécessaire. 


\section{Introduction}

As in many other countries, the construction sector in the occupied Palestinian territories is the largest industrial sector and has the highest accident rate [1-9]. The safety and protection of the workforce are therefore major concerns. Occupational health risks among construction workers are not limited to accidents. These workers are also among the highest occupational risk group for respiratory diseases, pneumoconiosis, skin diseases, back and musculoskeletal disorders and poisoning [10-16]. During recent phases of reconstruction in the occupied Palestinian territories, much of it funded by foreign aid money, priority was given to the achievements of the projects, possibly to the detriment of the safety of the workforce. Despite improved legislation regarding safety in the construction industry, first enacted in the year 2000 [17], the application of the Palestinian labour laws has not succeeded in reducing the rate of accidents in the West Bank and the rate of work injuries that occurred within the construction sector were reported by the Ministry of Labour (MoL) as 10.3\% and $13 \%$ for the years 2008 and 2009 respectively $[18,19]$.

The need for this present research stemmed from the lack of studies regarding safety in the construction industry in Palestine. The main aim of the study was to assess worker's experiences and perceptions of safety at construction sites in Hebron and Bethlehem governorates of the West Bank.

\section{Methods}

\section{Study setting and sample}

The area under study was Hebron and Bethlehem governorates in the southern part of the West Bank of Palestine. The study sample was people working in the building and construction trades. The total number of workers in this sector was estimated at about 4250. A sample of 349 workers were selected at random, taking into account 8 common activities: building, reinforced steel fixing, plastering, tiling, painting, stone pointing, electrical installations and sanitary installations. The size of the sample was determined using the procedure described by Hogg and Tannis [20].

\section{Data collection}

A questionnaire to collect construction workers' views and experiences of health and safety issues was designed for this study after a review of other studies in the literature. It was tested through interviews with a subsample of workers, and then amended. The questionnaire included 42 closed-ended questions and consisted of 5 main sections: general information, awareness and education, occupational health and safety, social safety and legislation. The questionnaire concerned the type of work done, actual experience of accidents or occupational diseases, workers' perceptions about safety risks and their causes, availability of safety equipment, working hours, work environment, as well as safety procedures, emergency plans and medical services, workers' education and awareness, site inspections, work and health insurance, work contracts and workers' awareness of the regulatory authorities.

The questionnaire was completed through direct interviews with the workers in the period from May to July 2010. The employers were first contacted to authorize the survey. Then the site managers or workers supervisors were informed and requested to brief the workers about the study objectives to facilitate the process of data collection.

\section{Analysis}

Analysis of data was carried out using SPSS, version 15. Correlation matrices and linear regression were used to assess the relationship between the different variables.

\section{Results}

The socioeconomic characteristics of the workers are shown in Table 1. Of the sample $99.4 \%$ were men, the greatest proportion were aged 16-20 years (44.5\%), had $1-3$ years experience (28.4\%), earned 1000-2000 shekels per month (49.9\%) and were unskilled labourers (30.7\%).

With respect to the perception of risks, the majority of respondents (85.1\%) perceived their job as risky. This proportion varied slightly according to the profession; the perception of risk was highest among stone-pointing technicians (92.9\%) (due to the risk of falls from unsafe scaffolding) and the lowest among painters (82.4\%).

The availability of first-aid tools, instructions and a trained specialist at the construction site is a safety requirement according to Palestinian labour laws. Of the survey respondents $69.4 \%$ were aware of the availability of first-aid materials at their construction site (Table 2). However, the survey also showed that many contracting companies were not complying with the requirement to hire a first-aid specialist at construction sites; only $10.7 \%$ of the respondents reported that a first aid specialist was available at the workplace, $65.6 \%$ said that one was not available, while $23.5 \%$ did not know whether there was a first aid specialist available or not (Table 2).

A total of 137 workers (39.3\%) reported that they were not using safety tools. When asked the reasons why not, $35.8 \%$ of this subgroup reported that safety tools were unavailable at the construction site, $13.1 \%$ that the tools were out of service, $10.9 \%$ did not know how use them, $14.6 \%$ worked indoors and $16.1 \%$ said did not like using them (Table 2).

Of the respondents $95.1 \%$ indicated that their main perceived risk was the risk of accidents while only $4.6 \%$ reported their main risk was occupational disease. This is borne out by workers' 


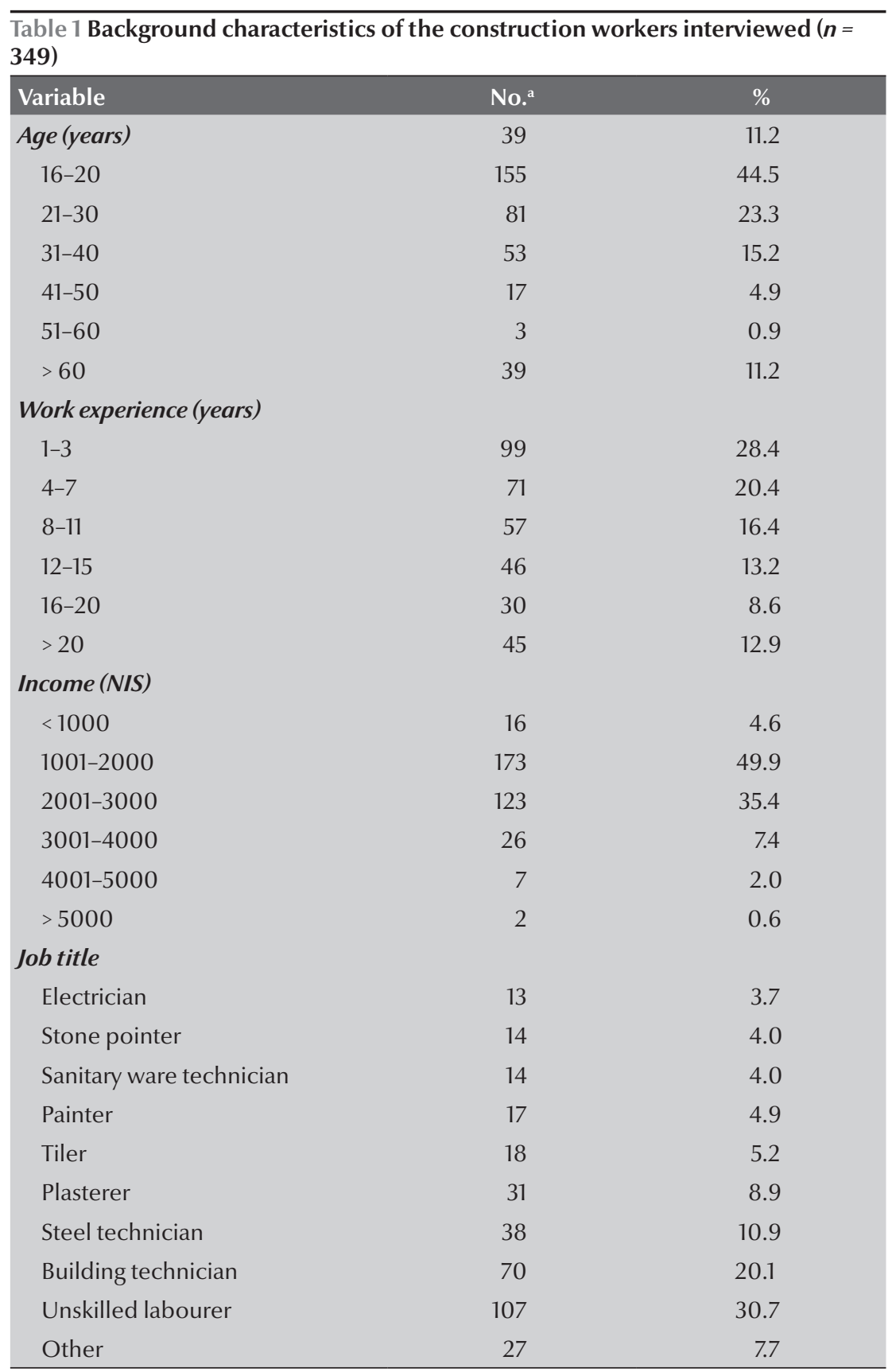

${ }^{a}$ Data missing in some categories.

NIS = new Israeli shekels.

actual experiences; $34.6 \%$ of respondents reported having ever experienced any work accidents in their lifetime but only $14.3 \%$ reported suffering from a work-related disease. As shown in Table 2 , the main cause of the accidents according the subgroup who had experienced them was carelessness (31.0\%), followed by lack of safety measures (22.5\%) and stress due to excessive overtime hours (15.5\%). organization with the greatest impact on the safety of the construction site were firstly the foreman (47.7\%), followed by the safety officer (17.8\%), the site engineer (12.9\%) and the project manager (12.0\%). Only $8.6 \%$ of respondents believed that the role of the regulatory authority was the most important. There was little variation in these opinions according to workers' job or seniority (Table 3 ).

When asked about effective strategies to promote a safety culture, respondent workers reported that safety training and education (47.7\%) and communication (33.6\%) would be the most effective, rather than inspection and enforcement (17.2\%). However, these strategies were not widely employed in reality, with only $16.3 \%$ of the workers reported having received any safety training, although $92.2 \%$ mentioned occasional (47.6\%) or frequent (44.7\%) promotion of safety during work by their supervisors. By contrast workers reported that their workplaces were inspected by the MoL frequently (10.3\%), occasionally $(28.7 \%)$ or never (61.0\%).

\section{Discussion}

Workers' perceptions about safety is an important element in promoting a safe working environment, as it contributes to the safety situation and allows the workers' point of view to be considered in formulating workers' safety policies in the construction sector. In general, this study suggests that the level of safety at workplaces in the West Bank was relatively low and building contractors were not taking safety issues into concern. However construction workers did show positive perceptions toward risks and safety.

A great majority of workers (85.1\%) perceived their job as risky, $35.8 \%$ reported that their work sites did not have safety tools and $34.6 \%$ had experienced at least one work-related 


\begin{tabular}{|c|c|}
\hline Item & $\%$ \\
\hline \multicolumn{2}{|l|}{ Is there a special first aid employee in your workplace? } \\
\hline Yes & 10.7 \\
\hline No & 65.6 \\
\hline Don't know & 23.7 \\
\hline \multicolumn{2}{|l|}{ Are there first aid materials in your workplace? } \\
\hline Yes & 69.4 \\
\hline No & 13.0 \\
\hline Don't know & 17.6 \\
\hline \multicolumn{2}{|l|}{ Why you are not using safety tools? $(n=137)$} \\
\hline Not available & 35.8 \\
\hline Inadequate/out of service & 13.1 \\
\hline Don't know how to use them & 10.9 \\
\hline Work indoors & 14.6 \\
\hline Don't like to use them & 16.1 \\
\hline Other reason & 9.5 \\
\hline \multicolumn{2}{|l|}{ Have you experienced work accidents? } \\
\hline Yes & 34.6 \\
\hline No & 65.4 \\
\hline \multicolumn{2}{|l|}{ What was the major cause of the accidents? $(n=116)$} \\
\hline Carelessness & 31.0 \\
\hline Lack of safety measures & 22.5 \\
\hline Stress due to excessive overtime & 15.5 \\
\hline Lack of experience & 10.1 \\
\hline Lack of maintenance of the equipment & 7.8 \\
\hline Inadequate tools & 5.4 \\
\hline Lack of respect of safety measures & 4.7 \\
\hline Low experience of site manager & 1.6 \\
\hline Use of equipment beyond its capacity & 0.8 \\
\hline Other reason & 0.8 \\
\hline \multicolumn{2}{|l|}{$\begin{array}{l}\text { In your opinion, what is the most frequent factor that } \\
\text { may affect workers'safety? }\end{array}$} \\
\hline Risk perceptions of workers and contractors & 16.1 \\
\hline Experience of both contractors and workers & 14.1 \\
\hline Educational level of workers and contractors & 9.5 \\
\hline Attitudes and behaviour of workers and contractors & 8.0 \\
\hline Monitoring and evaluation by regulatory authority & 4.9 \\
\hline Effectiveness of government rules and regulations & 3.4 \\
\hline Legislation and policy framework & 2.6 \\
\hline Safety measures and procedures & 1.7 \\
\hline Relationships between workers & 0.9 \\
\hline
\end{tabular}

accident. Only 14.3\% reported suffering from a work-related disease. The incidence of construction-related diseases in Palestine was reported by our workers as fairly low. This may be due to the simple type and typically small size of projects compared with other countries.

The greatest influence on safety according to workers' perceptions was the foreman. This role generally requires a greater degree of experience and higher level of education than for other workers. The foreman has the most frequent contact with workers at the construction site, assigning tasks and monitoring performance, and is the person specifying the ways in which the work is to be performed and skilled enough to identify unsafe situations.

Accidents may be a result of techni$\mathrm{cal}$ and/or managerial failing. Workers reported that the main causes of accidents were carelessness by workers, absence of safety measures and stress due to excessive overtime work. However, weak implementation of the government safety laws could be the root cause as this enables violations (e.g. not securing safety tools and forcing excessive overtime) to occur without punishment. Similarly, contracting agencies avoid detailing occupation health and safety restrictions, leaving the contractor without benchmarks and therefore no penalties in case these safety standards are not reached. The lack of appropriate training and education was another perceived cause of accidents according to workers. Other studies showed that accidents in the construction industry occur due to 3 root causes: failure to identify unsafe conditions before the activity, decision to proceed despite the identification of unsafe conditions and decision to work regardless the conditions of the work environment $[8,21]$. Some of our workers identified inadequate tools and a very few suggested use of equipment beyond its capacity as causes of accidents.

Only $10.7 \%$ of respondents knew that there was a first-aid worker at their place of employment and $23.5 \% \mathrm{did}$ not know. Of this latter group, they may or may not have been provided with a first-aid specialist, but the fact they were not aware of their presence indicates knowledge regarding safety is low. 


\begin{tabular}{|c|c|c|c|c|c|c|c|}
\hline \multirow[t]{3}{*}{ Job title } & \multirow{2}{*}{$\begin{array}{c}\text { Total } \\
\text { responses }\end{array}$} & \multicolumn{6}{|c|}{ Role/position with most impact on workplace safety } \\
\hline & & $\begin{array}{l}\text { Safety } \\
\text { officer }\end{array}$ & Foreman & $\begin{array}{l}\text { Project } \\
\text { manager }\end{array}$ & $\begin{array}{l}\text { Regulatory } \\
\text { authoritya }\end{array}$ & $\begin{array}{c}\text { Site } \\
\text { engineer }\end{array}$ & Other \\
\hline & No. & $\%$ & $\%$ & $\%$ & $\%$ & $\%$ & $\%$ \\
\hline Building technician & 70 & 18.6 & 44.3 & 7.1 & 7.1 & 18.6 & 4.3 \\
\hline Steel technician & 38 & 31.6 & 50.0 & 13.2 & 5.3 & 0.0 & 0.0 \\
\hline Plasterer & 31 & 19.4 & 38.7 & 16.1 & 9.7 & 16.1 & 0.0 \\
\hline Tiler & 18 & 5.6 & 50.0 & 5.6 & 5.6 & 33.3 & 0.0 \\
\hline Pointing technician & 14 & 14.3 & 57.1 & 0.0 & 14.3 & 14.3 & 0.0 \\
\hline Painter & 17 & 41.2 & 29.4 & 11.8 & 5.9 & 11.8 & 0.0 \\
\hline Unskilled labourer & 107 & 11.2 & 51.4 & 15.9 & 8.4 & 13.1 & 0.0 \\
\hline Electrician & 12 & 16.7 & 41.7 & 16.7 & 8.3 & 16.7 & 0.0 \\
\hline Sanitary ware technician & 14 & 21.4 & 57.1 & 7.1 & 7.1 & 7.1 & 0.0 \\
\hline Other & 27 & 14.8 & 51.9 & 14.8 & 18.5 & 0.0 & 0.0 \\
\hline Total & 348 & 17.8 & 47.7 & 12.1 & 8.6 & 12.9 & 0.9 \\
\hline
\end{tabular}

${ }^{a}$ Ministry of Labour.

Safety training and education were believed by our workers to be the elements with the greatest impact on construction site safety. This agrees with Dingsdag et al., who found that occupation health and safety training and education is the most important element for safe performance [22]. Communication with the workers was identified by our sample as the second key element essential to improving worksite safety. Good communication enables effective feedback about the safety of the workplace and workers' concerns, which can contribute to improved safety situations.

\section{Conclusion}

In general, the current level of safety on construction sites was perceived as low by workers and the lack of enforcement of safety rules was believed to be the root cause of this.
Site management and experienced human resources such as foremen and safety officers were perceived as having the greatest influence on site safety. In general, our results suggest that the MoL is not paying enough attention to the safety of workers in the construction industry, enabling the labour law violations indicated by workers themselves. Further efforts are required to implement the safety legislations in the Occupied Palestinian Territory.

\section{References}

1. Ahmed SM et al. Site safety management in Hong Kong. Journal of Management Engineering, 2000, 16:34-42.

2. Choudhry RM, Fang D. Why operatives engage in unsafe work behaviour: investigating factors on construction sites. Safety Science, 2008, 46:566-584.

3. Jaillon $\mathrm{L}$ et al. Quantifying the waste reduction potential of using prefabrication in building construction in Hong Kong. Waste Management, 2009, 29:309-320.

4. Koehn E, Kothari, R, Pan C. Safety in developing countries: professional and bureaucratic problems. Journal of Construction Engineering and Management, 1995, 121:261-265.

5. Camino López MA et al. Construction industry accidents in Spain. Journal of Safety Research, 2008, 39:497-507.

6. Mohamed S, Ali TH, Tam WYV. National culture and safe work behaviour of construction workers in Pakistan. Safety Science, 2009, 47:29-35
7. Sawacha E et al. Factors affecting safety performance on construction sites. International Journal of Project Management, 1999, 127:337-344.

8. Teo EA, Ling FYY, Chong AFW. Framework for project managers to manage construction safety. International Journal of Project Management, 2005, 23:329-341.

9. Törner M, Pousette A. Safety in construction-a comprehensive description of the characteristics of high safety standards in construction work, from the combined perspective of supervisors and experienced workers. Journal of Safety Research, 2009, 40:399-409.

10. Gyi DE, Haslam RA, Gibb AG. Case studies of occupational health management in the engineering construction industry. Occupational Medicine, 1998, 48:263-271.

11. Steenland K, Brown D. Silicosis among gold miners: exposureresponse analyses and risk assessment. American Journal of Public Health, 1995, 85:1372-1377. 
12. Steenland K et al. International Agency for Research on Cancer. Pooled exposure-response analyses and risk assessment for lung cancer in 10 cohorts of silica-exposed workers: an IARC multicentre study. Cancer Causes and Control, 2001, 12:773-784.

13. Tjoe Nij E et al. Dust control measures in the construction industry. Annals of Occupational Hygiene, 2003, 47:211-218.

14. Uter W et al. Contact allergy in construction workers: results of a multifactorial analysis. Annals of Occupational Hygiene, 2004, 48:21-27.

15. Rühl R, Hadrich D. Cement induced skin damage. Croner's Occupational Hygiene. Magazine, 2001, 29:17-23.

16. Sauni R et al. Increased risk of asthma among Finnish construction workers. Occupational Medicine, 2003, 53:527-531.
17. Palestinian labour law and secondary legislations. Ramalla, Palestine, Democracy and Workers Rights Centre, 2007.

18. Work Inspection Commission. Annual report. Ramalla, Palestine, Ministry of Labour, 2008.

19. Work Inspection Commission. Annual report. Ramalla, Palestine, Ministry of Labour, 2009.

20. Hogg RV, Tannis EA. Probability and statistical interferences, London, Prentice Hall, 1997.

21. Abdelhamid TS, Everett JG. Identifying root causes of construction accidents. Journal of Construction Engineering and Management, 2000, 126:52-60.

22. Dingsdag DP, Biggs HC, Sheahan VL. Understanding and defining $\mathrm{OH} \& \mathrm{~S}$ competency for construction site positions: Workers perception. Safety Science, 2008, 46:619-633.

\section{Safety 2012}

Safety 2012 is the 11th World Conference on Injury Prevention and Safety Promotion and is being held from 1 to 4 October 2012 in Wellington, New Zealand. The conference is held biennially under the auspices of the World Health Organization. It brings together the world's leading injury prevention and safety researchers, practitioners and advocates, to build our knowledge and strengthen the fields of injury prevention and safety promotion worldwide.

The overall theme of Safety 2012 is Connecting pathways for a vibrant and safer future. Within this context, specific themes being addressed at the conference are: i) Safety, design and sustainability - adopting a "sustainable environmental" approach to injury prevention; ii) Evidence for effective practice and programmes - promoting the evidence for injury prevention and control "solutions/interventions" that work; iii) Translating research and policy - the "implications/ impacts" of research and policy on promoting injury prevention

Further information about the conference is available at: http://www.conference.co.nz/worldsafety2012/home 